\title{
Food Studies
}

An Interdisciplinary Journal

\section{Social Self-Organization and Social- Ecological Resilience in Food Systems}

Lessons from Smallholder Agriculture in Kenya and Indigenous Guaraní Communities in Bolivia 
FOOD STUdiEs: An INTERdisCiPLINARY JOURNAL

https://food-studies.com

ISSN: 2160-1933 (Print)

ISSN: 2160-1941 (Online)

http://doi.org/10.18848/2160-1933/CGP (Journal)

First published by Common Ground Research Networks in 2020 University of Illinois Research Park

2001 South First Street, Suite 202

Champaign, IL 61820 USA

$\mathrm{Ph}:+1-217-328-0405$

https://cgnetworks.org

Food Studies: An Interdisciplinary Journal

is a peer-reviewed, scholarly journal.

\section{COPYRIGHT}

(C) 2020 (individual papers), the author(s)

(C) 2020 (selection and editorial matter),

Common Ground Research Networks

\section{(우(1) $\circledast$}

Some Rights Reserved

Public Licensed Material: Available under the terms and conditions of the Creative Commons

Attribution-NonCommercial-NoDerivatives 4.0 International Public License (CC BY-NC-ND 4.0). The use of this material is permitted for non-commercial use provided the creator(s) and publisher receive attribution. No derivatives of this version are permitted. Official terms of this public license apply as indicated here: https://creativecommons.org/licenses/by-nc-nd/4.0/legalcode

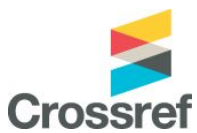

Common Ground Research Networks, a member of Crossref
EDITOR

Courtney Thomas, Virginia Polytechnic Institute and State University, USA

ACTING DIRECTOR OF PUBLISHING

Jeremy Boehme, Common Ground Research Networks, USA

\section{MANAGING EDITOR}

Megan Donnan, Common Ground Research Networks, USA

\section{ADVISORY BOARD}

The Advisory Board of the Food Studies Research Network recognizes the contribution of many in the evolution of the Research Network. The principal role of the Advisory Board has been, and is, to drive the overall intellectual direction of the Research Network. A full list of members can be found at

https://food-studies.com/about/advisory-board.

\section{PEER REVIEW}

Articles published in Food Studies: An Interdisciplinary Journal are peer reviewed using a two-way anonymous peer review model. Reviewers are active participants of the Food Studies Research Network or a thematically related Research Network. The publisher, editors, reviewers, and authors all agree upon the following standards of expected ethical behavior, which are based on the Committee on Publication Ethics (COPE) Core Practices. More information can be found at

https://cgnetworks.org/journals/publication-ethics.

\section{ARTICLE SUBMISSION}

Food Studies: An Interdisciplinary Journal

publishes quarterly (March, June, September, December)

To find out more about the submission process, please visit

https://food-studies.com/journal/call-for-papers.

\section{ABSTRACTING AND INDEXING}

For a full list of databases in which this journal is indexed, please visit https://food-studies.com/journal

\section{RESEARCH NETWORK MEMBERSHIP}

Authors in Food Studies: An Interdisciplinary Journal are members ofthe Food Studies Research Network or a thematically related Research Network. Members receive access to journal content. To find out more, visit

https://food-studies.com/about/become-a-member.

\section{SUBSCRIPTIONS}

Food Studies: An Interdisciplinary Journal

is available in electronic and print formats. Subscribe to gain access to content from the current year and the entire backlist.

Contact us at cgscholar.com/cg_support.

\section{ORDERING}

Single articles and issues are available from the journal bookstore at https://cgscholar.com/bookstore.

\section{HYBRID OPEN ACCESS}

Food Studies: An Interdisciplinary Journal

is Hybrid Open Access, meaning authors can choose to make their articles open access. This allows their work to reach an even wider audience, broadening the dissemination of their research. To find out more, please visit

https://cgnetworks.org/journals/hybrid-open-access.

\section{DISCLAIMER}

The authors, editors, and publisher will not accept any legal responsibility for any errors or omissions that may have been made in this publication. The publisher makes no warranty, express or implied, with respect to the material contained herein. 


\title{
Social Self-Organization and Social-Ecological Resilience in Food Systems: Lessons from Smallholder Agriculture in Kenya and Indigenous Guaraní Communities in Bolivia
}

\begin{abstract}
Mukhovi Stellah, ${ }^{1}$ University of Nairobi, Kenya
Johanna Jacobi, University of Bern, Switzerland

Aymara Llanque, Universidad Mayor de San Simón, Cochabamba, Bolivia

Stephan Rist, University of Bern, Switzerland

Freddy Delgado, Agruco, Universidad Mayor de San Simón, Cochabamba, Bolivia

Boniface Kiteme, Centre for Integrated Training and Research in ASAL Development, Kenya

Chinwe Ifejika Speranza, University of Bern, Switzerland

Abstract: Food systems face pressures related to global environmental change and agricultural intensification that make access to productive resources difficult for many actors. Social self-organization is one of the measures taken by actors to enable them to increase their capacity to mitigate challenges and increase their influence as well as build resilience against risks. The objectives of this study were to assess the level of social self-organization in food systems, to identify forms of social self-organization and the motivations behind them, and to analyze the benefits to food systems socialecological resilience. We collected data from various actor groups at different levels of food systems using mixed methods. Analysis involved six indicators that were scored on a Likert scale. The study observed that smallholders in Kenya organized in women's self-help groups, agro-ecological movements, and cooperatives, while in Bolivia the Guarani indigenous people organized in movements addressing territorial integrity. Social self-organization was found to be important in resilience building at a community level and has potential to contribute to more sustainable food systems. However, more research on the link between social self-organization and policy change across scales would provide additional interesting insights.
\end{abstract}

Keywords: Social Self-Organization, Food Systems, Resilience, Kenya, Bolivia

\section{Introduction}

$\mathrm{H}$ unger, undernourishment, and malnutrition remain major challenges to sustainable development in various world regions (FAO et al. 2017). Their drivers have not only been linked to inadequacies in local and regional food production, but also to problems in food processing, distribution, and consumption. Apart from inadequacies in the value chain, food systems also face a myriad of challenges associated with global environmental changes, socioeconomic pressures, and political shocks that affect food sustainability. Hence, an overview of food system resilience is necessary for a holistic understanding of these problems and for identifying solutions.

Food systems can be understood as social-ecological systems encompassing

Interdependent networks of stakeholders (companies, financial institution, and public and private organizations), localized in a given geographical area (region, state, multinational region) participating directly or indirectly in the creation of flow of goods and services geared towards satisfying the food needs of one or more group of consumers, both locally and outside the area considered. (Rastoin and Ghersi 2010, 19)

\footnotetext{
${ }^{1}$ Corresponding Author: Mukhovi Stellah, University of Nairobi, Department of Geography and Environmental Studies, Po Box 30197-00100, Nairobi, Kenya. E-mail; stellah.mukhovi@gmail.com; smmukhovi@uonbi.ac.ke
}

Food Studies: An International Journal

Volume 10, Issue 1, 2020, https://food-studies.com

(C) Common Ground Research Networks, Mukhovi Stellah, Johanna Jacobi,

Aymara Llanque, Stephan Rist, Freddy Delgado, Boniface Kiteme, Chinwe Ifejika Speranza

Some Rights Reserved, (CC BY-NC-ND 4.0). Permissions: cgscholar.com/cg_support

ISSN: 2160-1933 (Print), ISSN: 2160-1941 (Online)

https://doi.org/10.18848/2160-1933/CGP/v10i01/19-42 (Article) 
The interaction between social and ecological systems creates positive outcomes such as food and nutrition security, agro biodiversity, incomes, resilience, and environmental protection. Sometimes food systems may contribute to negative outcomes including poverty and inequality, environmental pollution, land degradation, and climate change. A food system approach provides an opportunity to identify enabling and/or hindering factors along the value chain and a chance to mitigate them to develop more sustainable future (Sari, Rikkonen, and Kahiluoto 2016).

In addition, food systems can be understood as consisting of sub-systems, including a political sub-system (institutions and laws, both hard and soft, that affect food production), an information and services sub-system (access to information, logistical services, research, extension), an operational sub-system (value chain functioning and activities and a sub-system of natural resources (soils, water, and energy) (Colonna, Fournie, and Taizard 2013; Esnouf, Russel, and Bricas 2013; Roberto et al. 2014).

Social-ecological resilience has become an important research subject for food systems due to their increasing susceptibility to multiple risks from global environmental changes (Ericksen 2008; Tendall et al. 2015). Resilience measures the amount of change a system can undergo and still retain its function and structure, the degree to which the system is capable of self-organization, and its ability to build and increase its capacity for learning and adaptation (Adger 2000; Folke et al. 2011; Cabell and Oelofse 2012; Folke 2016). Resilience studies often ask questions such as: Resilience to what? What are the threats or risks? Who is affected? How do they adapt to the risks? (Keck and Sakdapolrak 2013). In Bolivia and Kenya, several food system risks perceived by actors have already been identified: land degradation, water shortages, climate variability and climate change, pests and diseases, price fluctuation, excessive use of agrochemicals, loss of agrobiodiversity, and invasive species especially in rangelands (Jacobi et al. 2019).

Self-organization can be described as a characteristic of a system to change its structure as systems actors interact with their habitat. It can also be a response to either internal or external stimuli (Imada 2008). Self-organization can be studied in both ecological and social terms. While ecological self-regulation, as suggested by Cabell and Oelofse (2012), is important for selforganization and resilience, here we focus on the concept of social self-organization. Social selforganization can be defined as the ability of social entities such as communities, households, and individuals to come together to articulate issues of common interest (Hejl 1990; Fuchs 2006). Such groups often have their own reasons and causes and elect their own leaders and set rules of engagement to help meet intended objectives. Additionally, actors may self-organize at any stage of value chain-production, distribution, processing, retailing, and even at the point of consumption since challenges and opportunities may occur at any point within these networks. Social self-organization is different from social network theory, which views relationships between individuals or groups in terms of nodes and ties/links, where nodes are the individuals, also called movers, while ties are the social relations, interactions, and flows between them (Burt 2000).The opportunities and constraints associated with each actor depend on the position within the network. Unlike social self-organization, social network theory tends to assume that there are no external social factors/forces beyond the network participants (Carrington, Scott, and Stanley 2005; Wasserman, Jackson, and Rogers 2007). However, we regard groups as complex systems that do not exist in isolation from influence from outside the community and the food system, and who, due to the interaction between themselves, have a potential to influence policy (Arrow, McGrath, and Berdahl 2000)

Social aspects of resilience concern social entities such as individuals, households, and communities, and their abilities to tolerate, cope with, and adjust to environmental and social changes (Keck and Sakdapolrak 2013). At the household level, resilience depends on household income, access to food and assets such as livestock and land, institutions and entitlements, knowledge, and information (Dhraief et al. 2019). To be resilient, vulnerable groups require safety nets such as cash transfers, food assistance, and employment-based programs. Access to basic services, such as water and health care, is a necessity for all. Household adaptive capacity 
is influenced by the stability of all these factors over time (Resilience Alliance 2010; Elrick-Barr et al. 2014). There are two types of social resilience: capacity of communities to anticipate change, reduce vulnerabilities, and facilitate adaptation, and the capacity of a social-ecological system to sustain preferred modes of economic activity (Kofinas 2003; Kofinas and Stuart 2009; Davidson 2010). While it is important to build individual and/or household capacities for resilience, collective action exemplified in social self-organization is essential in enabling communities to determine their future together.

Social self-organization between and among food system actors has been identified as important for dealing with challenges facing social-ecological systems (Folke et al. 2002; Walker et al. 2004; Nkhata, Breen, and Freimund 2008), in particular for pulling together individual capacities to address challenges beyond the capacity of individual actors. Actors self-organize to address several challenges including high cost of farm inputs, fear of losing their land through encroachment by multinationals, extreme climatic events (Rigolot et al. 2017), and health related challenges associated with malnutrition and food safety, limited access to markets, risk of food shortages, food inaccessibility due to high prices, land degradation, water shortages, and conflicts. These challenges also create opportunities for food system actors to innovate and create more resilient futures (Ericksen et al. 2010).

There are other benefits associated with actors coming together, including cost minimization and benefit maximization (Wood and Gray 1991), and improved governance (Imperial 2004) Social self-organization in food systems refers in this study to strategies that the actors (e.g., producers, distributors, processing actors, retailers, and consumers) adopt in order to form groups, and the degree to which such groups can direct their own actions and outcomes to strengthen social aspects of resilience (Speranza, Urs, and Rist 2014). Social self-organization may allow, for example, for exchange of ideas and resources that may contribute to changes in behavior with positive outcomes that make food systems more resilient. However, empirical evidence of social self-organization in the context of food systems as a component of socialecological resilience is still scarce. The objectives of this study are to assess the level of social self-organization in food systems in Kenya and Bolivia, to identify forms of social selforganization and the motivation behind them, and to analyze the benefits to food systems' socialecological resilience.

\section{Materials and Methods}

\section{Study Sites and Food Systems Characterization}

We conducted parallel studies in Kenya and Bolivia using the same indicators in both contexts (see Cabell and Oelofse 2012). We used a typology of different food systems provided by Colonna, Fournie, and Taizard (2013). For the purpose of this article, we compare social selforganization in a local food system comprising of smallholders in Kenya, and an indigenous food system of the Guaraní people in Bolivia (Table 1). 
Table 1: Characteristics of Food Systems in Kenya and Bolivia

\begin{tabular}{|c|c|c|}
\hline & \multicolumn{2}{|c|}{ Characteristics } \\
\hline & Kenya & Bolivia \\
\hline Food System & $\begin{array}{l}\text { The food system under } \\
\text { investigation comprises of } \\
\text { smallholder farmers and local } \\
\text { markets based on maize, beans, } \\
\text { and potatoes. Most food } \\
\text { products grown are consumed at } \\
\text { household level with very } \\
\text { limited surplus sold at local } \\
\text { markets. Middlemen play } \\
\text { critical role in linking farmers to } \\
\text { markets and processing stage of } \\
\text { value chain. The main staple } \\
\text { food is made from maize with a } \\
\text { per capita consumption of } 98 \mathrm{~kg} \\
\text { per annum The food system is } \\
\text { influenced by large-scale wheat } \\
\text { production and agro-industrial } \\
\text { food system based on } \\
\text { horticulture. }\end{array}$ & $\begin{array}{l}\text { Bolivia is a net importer of staple } \\
\text { food (wheat and rice), and normally } \\
\text { self-sufficient in maize. This study } \\
\text { focuses on the indigenous food } \\
\text { system of the Guaraní people who } \\
\text { inhabit the Chaco region, and whose } \\
\text { most important staple food comes } \\
\text { from maize. Families also cultivate } \\
\text { beans, cassava, fruits, and a range of } \\
\text { other subsistence crops, and keep } \\
\text { chicken, ducks, goats and cows. } \\
\text { Most food products grown are } \\
\text { consumed at household level with } \\
\text { very limited surplus sold at local } \\
\text { markets. Middlemen play a role as } \\
\text { food sellers in Guaraní villages as } \\
\text { much of their food is exogenous. } \\
\text { The food system is characterized by } \\
\text { communal land titles, and highly } \\
\text { influenced by the surrounding and } \\
\text { expanding agro-industrial food } \\
\text { system, and crude oil and gas } \\
\text { extraction. }\end{array}$ \\
\hline Land Use & $\begin{array}{l}\text { Main crops grown include wheat, } \\
\text { maize, beans, potatoes, and } \\
\text { vegetables. Maize occupies } 51 \% \\
\text { of the total planted area. } \\
\text { Livestock is mainly integrated } \\
\text { with crops among smallholders } \\
\text { while in the much drier lowlands it } \\
\text { is the main source of livelihood }\end{array}$ & $\begin{array}{l}\text { Local production and consumption } \\
\text { based on different corn varieties } \\
\text { and Milpa systems (combinations } \\
\text { of corn, beans, and squash); } \\
\text { cassava, sweet potato, peanuts, } \\
\text { vegetables, and fruits, often in } \\
\text { mixed cropping systems and/or } \\
\text { agroforestry in home gardens. }\end{array}$ \\
\hline Rainfall & $\begin{array}{l}\text { Bimodal rainfall patterns with long } \\
\text { rains occurring in March to May } \\
\text { and short in October and } \\
\text { November. Annual rainfall is } 400 \\
\text { mm and } 750 \text { mm though higher } \\
\text { totals are observed on the areas } \\
\text { bordering the slopes of Mt. Kenya } \\
\text { and the Aberdare Ranges. }\end{array}$ & $\begin{array}{l}\text { Annual precipitation is } 700-1400 \\
\text { mm concentrated in one rainy } \\
\text { season of } 5-6 \text { months with highest } \\
\text { rainfalls from January to March. } \\
\text { The agricultural cycle in the Chaco } \\
\text { region is concentrated during the } \\
\text { rainy season. }\end{array}$ \\
\hline Soils & $\begin{array}{l}\text { Main soils in Laikipia part of the } \\
\text { study are loams, sand, and clay. } \\
\text { Black cotton soils common in } \\
\text { lowlands while dark reddish- } \\
\text { brown to red friable soils and } \\
\text { rocky soils are mainly found on } \\
\text { the hillsides while the lower slopes } \\
\text { of Meru County have Nitisols, } \\
\text { Cambisols, and Andosols }\end{array}$ & $\begin{array}{l}\text { Soils in the plains of the Chaco } \\
\text { region are normally neutral to } \\
\text { alkaline Inceptisols, Alfisols, } \\
\text { Entisols, and Vertisols. Suitability } \\
\text { for agricultural use is very low in } \\
\text { most parts. Large parts of the } \\
\text { Chaco region are used for extensive } \\
\text { cattle rearing. }\end{array}$ \\
\hline
\end{tabular}




\begin{tabular}{|l|l|l|}
\hline \multirow{2}{*}{} & \multicolumn{2}{|c|}{ Characteristics } \\
\cline { 2 - 3 } & \multicolumn{1}{|c|}{ Kenya } & \multicolumn{1}{c|}{ Bolivia } \\
\hline \multirow{5}{*}{ Population } & Population density in study area & The total population of the \\
& ranges between 42 persons per & Municipality of Cabezas was \\
& square kilometer in in drier & 28,000 in 2015, with 50\% under 19 \\
& lowlands while near slopes of Mt. & years old. Population density in the \\
& Kenya the population is much & Cabezas municipality is 1.53 \\
& higher in Meru (Government of & persons per square kilometer. \\
& Kenya (GOK) 2009). The majority & Guaranís in the Chaco region are \\
& (80\%) are Christians while the rest & divided into Catholics and \\
& are Muslims. The communities are & protestants (known as "cristianos,", \\
& mainly migrants from neighboring & members of Pentecostal churches), \\
& Counties of Nyeri, Kirinyaga, and & and sometimes also politically \\
& Murang'a & divided. \\
\hline
\end{tabular}

Source: Compiled by the Authors from GoK 2009; Meru County Integrated Development Plan 2013,

Laikipia County Integrated Development Plan 2013, Autonomous Municipal Government of Cabezas 2016

The Northwest Mount Kenya region is drained by Ewaso Ngiro River within Laikipia and Meru Counties (Figure 1). The area is located between 0020'N and 0040'S and 36040' and 37040 'E. The climate conditions depend on the proximity to Mount Kenya, where rainfall drastically reduces with increasing distance from the mountain, thus contributing to a wide range of agro-ecological zones. The rainfall is highly variable and ranges between 400 and $2500 \mathrm{~mm}$ per annum, and it is bimodal with longer rains between March and May, and shorter rains between October and December (Lanari, Liniger, and Kiteme 2016; Peter et al. 2018). The different rainfall patterns and agro-ecological zones have contributed to diverse agricultural activities including beef ranching, horticulture, dairying, and large-scale wheat and barley production, in addition to smallholder agriculture, that forms the focus of our investigation.

The study area in Bolivia lies in the lowlands of the Santa Cruz department, whose capital city, Santa Cruz de la Sierra, is located at $17^{\circ} 48^{\prime} \mathrm{S}$ and $63^{\circ} 11^{\prime} \mathrm{W}$. Annual precipitation is about $1400 \mathrm{~mm}$ concentrated in one rainy season with a peak in December-February. The agricultural cycle is concentrated in the rainy season. Livestock rearing (cows and goats), including dairying, complements agricultural activities. However, population density is only 1.53 persons per square kilometer. Large-scale soybean and sesame farming surrounds smaller communal land of indigenous Guaraní communities. The food system of the Guaraní peoples can, for instance, be found in the Municipality of Cabezas (Figure 1), while also being influenced by other, for instance, agro-industrial and agro-ecological food systems.

The two food systems show differences as well as similarities: the main food crops are maize, beans, vegetables, and tubers (cassava for Guaraní, and potatoes for smallholders in Kenya). Furthermore the farmers practice mixed farming where crops are integrated with livestock. Another common aspect is that the households are marginalized in terms of access to government services (extension, development projects, subsidies etc.). Finally, most of the food produced is consumed at a household level and any surplus is sold to the local market. The two food systems differ in terms of farm sizes: smallholders in Kenya had less than 2 ha of family-owned land as compared to around 8,000 ha of Guaraní communal land in the Municipality of Cabezas, used by around 400 families in eleven communities through individual, usufruct land rights. 


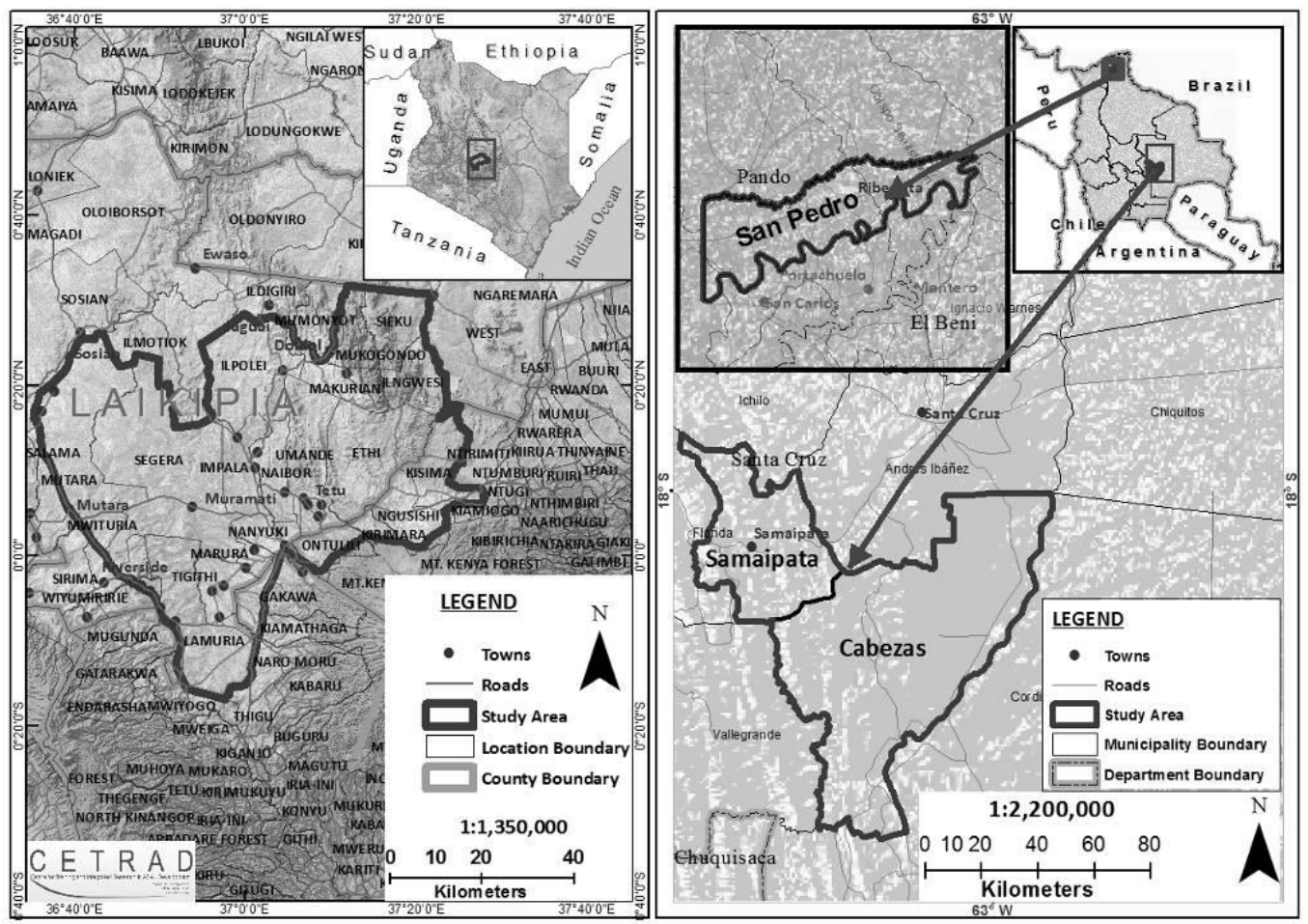

Figure 1: Study Area in Kenya and Bolivia

Source: CETRAD 2017

\section{Indicators for Social Self-Organization}

Self-organization is one important pillar of social-ecological resilience besides buffer capacity and the capacity for learning and adaptation (Carpenter et al. 2001). Social self-organization allows for re-organization after a shock and for re-establishing system functions. Following Cabell and Oelofse (2012) and Speranza, Urs, and Rist (2014), we identified the following indicators to assess social self-organization (Table 2): 1) whether the actors belonged to any group whose activities are related to food system activities; 2) trust relationships (e.g., whether or not different food system actors connected via value chains trust each other, and whether or not they find trust important, how trust is built, and with whom; 3) if the food system provides a Livable Income referring to whether or not monthly wages or incomes from food system activities were above minimum wages; 4) connectivity within the food system referring to the quantity and quality of connections (e.g., if they create dependency or not, and if there is competition or cooperation); 5) decentralization and independence, meaning, for example, reliance on local resources, short economy cycles, direct trade relations. This indicator refers originally to "interdependence," but here we apply it to determine a degree of self-sufficiency, and address "interdependence" in the connectivity of food system components); and 6) the level of local production and consumption, either on-farm or within the community. 
Table 2: Indicators for Social Self-Organization

\begin{tabular}{|c|c|c|c|c|c|}
\hline \multirow{2}{*}{ Indicator } & \multicolumn{5}{|c|}{ Rating Criteria } \\
\hline & $\mathbf{0}$ & 1 & 2 & 3 & 4 \\
\hline $\begin{array}{l}\text { Decentralization and } \\
\text { Independence }\end{array}$ & $\begin{array}{l}\text { All inputs are } \\
\text { external; } \\
\text { markets } \\
\text { external }\end{array}$ & $\begin{array}{l}\text { Most inputs } \\
\text { and } \\
\text { knowledge } \\
\text { are external; } \\
\text { market is } \\
\text { external; } \\
\text { however, } \\
\text { some local } \\
\text { loops such as } \\
\text { reproduction } \\
\text { of seeds can } \\
\text { be identified. }\end{array}$ & $\begin{array}{l}\text { Inputs and } \\
\text { markets are } \\
\text { partly external } \\
\text { and partly local }\end{array}$ & $\begin{array}{l}\text { Only parts of } \\
\text { the inputs (e.g. } \\
\text { some seeds or } \\
\text { some } \\
\text { specialized } \\
\text { knowledge) } \\
\text { comes from } \\
\text { non-local } \\
\text { sources, } \\
\text { markets are } \\
\text { mainly local. }\end{array}$ & $\begin{array}{l}\text { No external } \\
\text { inputs or } \\
\text { markets }\end{array}$ \\
\hline $\begin{array}{l}\text { Appropriately } \\
\text { connected }\end{array}$ & $\begin{array}{l}\text { No } \\
\text { connections, } \\
\text { cooperation and } \\
\text { bargaining } \\
\text { power }\end{array}$ & $\begin{array}{l}\text { Indication of } \\
\text { connection or } \\
\text { cooperation or } \\
\text { bargaining } \\
\text { power } \\
\text { between food } \\
\text { system stages }\end{array}$ & $\begin{array}{l}\text { Connection } \\
\text { and } \\
\text { cooperation } \\
\text { between some } \\
\text { but not all food } \\
\text { system stage } \\
\text { and/or food } \\
\text { systems. Low } \\
\text { bargaining } \\
\text { power of most } \\
\text { food system } \\
\text { actors. }\end{array}$ & $\begin{array}{l}\text { All food } \\
\text { system stages } \\
\text { and/or food } \\
\text { systems are } \\
\text { connected, but } \\
\text { not all } \\
\text { cooperate with } \\
\text { each other, } \\
\text { and not all } \\
\text { have a high } \\
\text { bargaining } \\
\text { power }\end{array}$ & $\begin{array}{l}\text { All food } \\
\text { system stages } \\
\text { and/or food } \\
\text { systems are } \\
\text { connected, and } \\
\text { have similar } \\
\text { bargaining } \\
\text { power }\end{array}$ \\
\hline $\begin{array}{l}\text { Local consumption } \\
\text { of production }\end{array}$ & $\begin{array}{l}\text { No food is } \\
\text { consumed } \\
\text { locally }\end{array}$ & $\begin{array}{l}\text { Up to } 25 \% \\
\text { of food } \\
\text { produced is } \\
\text { consumed } \\
\text { locally }\end{array}$ & $\begin{array}{l}25-50 \% \text { of } \\
\text { food produced } \\
\text { is consumed } \\
\text { locally }\end{array}$ & $\begin{array}{l}50-75 \% \text { of } \\
\text { food } \\
\text { produced is } \\
\text { consumed } \\
\text { locally }\end{array}$ & $\begin{array}{l}75-100 \% \text { of } \\
\text { food produced } \\
\text { is consumed } \\
\text { locally }\end{array}$ \\
\hline Livable Income & $\begin{array}{l}\text { Food system } \\
\text { activities do } \\
\text { not create a } \\
\text { livable wage } \\
\text { (above } \\
\text { minimum } \\
\text { wage) at any } \\
\text { of the value } \\
\text { chain stages. }\end{array}$ & $\begin{array}{l}\text { System } \\
\text { activities } \\
\text { create a } \\
\text { livable wage } \\
\text { at one value } \\
\text { chain stage }\end{array}$ & $\begin{array}{l}\text { System activities } \\
\text { create a Livable } \\
\text { Income at more } \\
\text { than one value } \\
\text { chain stage; }\end{array}$ & $\begin{array}{l}\text { System } \\
\text { activities } \\
\text { create a } \\
\text { livable wage } \\
\text { at all value } \\
\text { chain stages } \\
\text { for directly } \\
\text { involved } \\
\text { actors }\end{array}$ & $\begin{array}{l}\text { System } \\
\text { activities } \\
\text { create a } \\
\text { Livable } \\
\text { Income at all } \\
\text { value chain } \\
\text { stages for }\end{array}$ \\
\hline Interest Groups & $\begin{array}{l}\text { No interest } \\
\text { group identified } \\
\text { in none of the } \\
\text { food system } \\
\text { stages and at } \\
\text { none of the } \\
\text { local to global } \\
\text { scales. }\end{array}$ & $\begin{array}{l}\text { Very few } \\
\text { interest } \\
\text { groups only in } \\
\text { one or two } \\
\text { food system } \\
\text { stages and } \\
\text { restricted to } \\
\text { the local level }\end{array}$ & $\begin{array}{l}\text { More than one } \\
\text { interest group in } \\
\text { more than two } \\
\text { food system } \\
\text { stages, not } \\
\text { restricted to the } \\
\text { local or only one } \\
\text { scale. }\end{array}$ & $\begin{array}{l}\text { Various } \\
\text { interest groups } \\
\text { covering more } \\
\text { than two food } \\
\text { system stages } \\
\text { from local to } \\
\text { international } \\
\text { scales. }\end{array}$ & $\begin{array}{l}\text { Various } \\
\text { interest groups } \\
\text { in all food } \\
\text { system stages } \\
\text { covering all } \\
\text { scales from } \\
\text { local to global. }\end{array}$ \\
\hline
\end{tabular}




\begin{tabular}{|c|c|c|c|c|c|}
\hline \multirow{2}{*}{ Indicator } & \multicolumn{5}{|c|}{ Rating Criteria } \\
\hline & $\mathbf{0}$ & 1 & 2 & 3 & 4 \\
\hline Trust Relationships & $\begin{array}{l}\text { No indication } \\
\text { of trust } \\
\text { among actors } \\
\text { of the } \\
\text { different food } \\
\text { system stages } \\
\text { along the } \\
\text { value chain. }\end{array}$ & $\begin{array}{l}\text { Very few } \\
\text { and low } \\
\text { indications } \\
\text { of trust } \\
\text { among food } \\
\text { system } \\
\text { actors of } \\
\text { different } \\
\text { food system } \\
\text { stages. }\end{array}$ & $\begin{array}{l}\text { Some } \\
\text { connections } \\
\text { that are } \\
\text { characterized } \\
\text { by trust } \\
\text { relationships } \\
\text { between } \\
\text { different food } \\
\text { system stages, } \\
\text { e.g. between } \\
\text { extension } \\
\text { services and } \\
\text { production, } \\
\text { consumer and } \\
\text { producer, or } \\
\text { between } \\
\text { enterprises }\end{array}$ & $\begin{array}{l}\text { There is a high } \\
\text { level of } \\
\text { relationships } \\
\text { that are built } \\
\text { on trust } \\
\text { between more } \\
\text { than two food } \\
\text { system stages. }\end{array}$ & $\begin{array}{l}\text { Trust } \\
\text { relationships } \\
\text { connecting all } \\
\text { food system } \\
\text { stages }\end{array}$ \\
\hline
\end{tabular}

Source: Stellah et al. 2019

\section{Data Collection Methods}

In Kenya, data were collected from twenty-five randomly sampled smallholders using a semistructured questionnaire. The small sample was attributed to a large number of researchers in the project that were studying the same population on different topics hence effort was made to minimize fatigue among the respondents. Our aim was to find out how many farmers belonged to groups in a random sample and then follow up those who had membership to groups with more questions. The questionnaires were administered to household heads or in their absence a senior member by two trained research assistants. A research assistant from one of the communities where we collected data helped to translate the questions verbally into the Kikuyu and Meru languages, which are widely spoken by the communities in Laikipia and Meru Counties. Additionally, one focus group discussion was conducted with a women's group (with a senior researcher as key facilitator helped by two research assistants from the community). Key informant interviews provided information on social self-organizations related to food systems such as Common Interest Groups (CIGs), cooperatives, Community Forest Association (CFAs), and Water Resource Users Associations (WRUAs). More information on social self-organization and its link to resilience building came from five retailers/middlemen; three wholesalers (who market products from smallholders in the study area); five restaurants (that prepare traditional foods); fourteen organizations that deal with resilience building and risk mitigation (NGOs); a nutritional health expert; representatives of the national and county governments of Laikipia and Meru; relevant ministries; programs such as Agriculture Sector Development Support Program (ASDSP); and research organizations such as Kenya Agriculture and Livestock Research Organisation (KALRO).

In Bolivia, we interviewed six representatives from local organizations working with, or knowledgeable of, the Guaraní food system (National Agriculture and Forestry Innovation Institute (INIAF), Probioma, Fundacion Tierra, Center for Peasantry Research and Promotion (CIPCA), Pastoral Social Caritas, and the Guaraní People's Assembly). We did not use questionnaires; our major focus was rather on participatory research methods with longer research stays (in the frame of one doctoral and two master's theses) to get to know local families and their food and production habits. The third author conducted doctoral research on indigenous food system of the Guaraní in the municipality of Cabezas and the authors also conducted several (shorter) research stays as well as workshops on topics that the communities identified as crucial to their food system (e.g., biological control of pests and diseases on crops). Translators were not 
involved. The topics of how the actors of this food system organized and the respective indicators were deepened in five participatory workshops and participant observation in four assemblies with the local food system actors in the municipality of Cabezas, in the two villages of Yatirenda and La Ripiera. The participants in the workshops were Guaraní families (most participants were women), food vendors, agricultural advisors, and decision-makers.

\section{Data Analysis}

In order to understand forms, motivations, and benefits of self-organization in food systems, first, we assessed membership in interest groups, including levels of cooperation between food system actors, and the aspect of trust and transparency among food system actors. Secondly, we analyzed a) the forms of social self-organization and associated benefits; b) interaction between different food systems, e.g., in terms of specific strategies and bargaining power of different actors; c) local consumption of food products; and d) if the food system provides a Livable Income. The data were subjected to content analysis using the program Atlas.ti (version 7.5.2) and coded according to the indicators of social self-organization and processed in Excel sheets. The results for the indicators were rated and compared in a joint workshop by the team on a Likert scale ranging from 0 to 4 . A Likert scale is an ordinal rating scale used to measure attitudes, opinions, and perceptions about specific topics. The scale can be measured in terms of agreement (strongly agree to strongly disagree), value (none, low, moderate, high), or frequency (never to very frequently). In this study we used values to rate the level of social selforganization as: non-existent (0); low (1) if activities take place at only one food system stage, and are restricted to one level; medium (2) if few activities cut across at least two food system stages and different levels; high (3) several activities at different stages and levels; and very high/ideal (4) if all food system stages are involved, and if the activities are diverse and crossscale. "Livable income" was rated according to its relation to the official minimum wage (which represented "low," i.e., 1). The total number of scores for each aspect of social self-organization e.g. trust were added and a mean score calculated which was then rounded to nearest whole number to improve on the clarity of the final assessment.

\section{Results and Discussion}

\section{Social Self-Organization in Smallholder Agriculture and Indigenous Food System}

The results show that 48 percent of the smallholders in Kenya belonged to groups related to food systems. These groups had diverse interests, ranging from ecological, economic and social. Motivation behind social self-organization mentioned by respondents included increased welfare, access to credit, and the desire to acquire new knowledge and access to markets. Several groups existed that met different challenges such as ecological problems related to forest and water management, and welfare, like self-help groups dominated by women but whose agendas also included resilience building.

The situation in Bolivia was different from the case study in Kenya. The indigenous food system had, on the one hand, social groups within the villages such as women's groups. On the other hand, they were integrated into regionally active organizations beyond the local communities linking production and consumption levels, and based mainly on territorial integrity and access to income from natural resources exploited from their lands. There were two predominant organizational forms: the Capitanías, groups of Guaraní communities in territories based on a legally recognized local governance system, and the overarching organizations Guaraní People's Assembly (APG; Asamblea del Pueblo Guaraní in Spanish) that advocated for land rights as a basis for food production, villages, and income generation for Guaraní communities. 


\section{Forms of Social Self-Organization in Kenya and Bolivia}

In Kenya, smallholders self-organized to meet diverse needs. The groups focused on welfare, table banking, ${ }^{2}$ and security. Some examples of groups include WRUAs, CFAs, and cooperatives especially for milk producers, CIGs and nyumba kumi ("ten houses"- -an initiative promoted by government to enhance security based on people knowing who their neighbors are). WRUAs were by far the most common forms of social self-organization due to the need to get access to water - a contested resource in the region under study. The Kenyan constitution of 2010 elevated water and food to a human rights issue: Section 43 (1) d states that "every person has a right to clean and safe water in adequate quantities" while Article 43 establishes Kenyans' right "to be free from hunger and have adequate food of acceptable quality." The Bolivian constitution has also elevated right to food as a human right issue.

The water regulations in Kenya provides for the formation of WRUAs, i.e., local institutional bodies set up by water users to enable communities to participate in co-management of water resources. Although participatory natural resources management is provided for in the legal frameworks, Community Based Organizations (CBOs) and other civil society groups had to lobby for many years for changes in legislation to allow for communities to access various rights in over natural resources such as water, forests and wildlife. One CFA representative confirmed that they were initially a $\mathrm{CBO}$ and it took them nine years of negotiation with the government (2002-2010) to eventually be allowed to cultivate in the forest. It is also important to note that most of the CFAs began as CBOs that expanded their activities to demand user rights over forests. In Kenya we observed high heterogeneity among the membership of smallholders and large-scale horticulture producers who also depended on the same surface water for irrigation (Peter et al. 2018; Lanari et al. 2018). WRUAs not only manage the water resources but also form community water projects that help the communities to access water (Mutea, Rist, and Jacobi 2020). However, a large proportion of smallholders are frequently excluded due to inability to pay monthly fees, while permits to abstract water are readily provided to large-scale producers (Ulrich 2014; Lanari 2014; Lanari, Liniger, and Kiteme 2016).

In contrast, in Bolivia most of the forms of social self-organization were related to land and family issues. The Guaraní people organized themselves around land issues in the APG, an international organization (the Guaraní people live also in Brazil, Argentina, Uruguay, and Paraguay). Locally, they are organized in Capitanías which have recently gained importance locally due to increased organization around conflictive exploitation of crude oil and gas on Guaraní communal lands. On the other hand, the Guaraní women were organized in groups that gathered and worked together, for example, cooking or running kitchen gardens, and undertaking reciprocity activities for the community such as organizing festivities or exchange of food. Such reciprocity activities were also common among smallholders in Kenya where members of women groups helped each other in funerals, weddings and during sickness by cultivating for the sick member. Women groups in both countries were associated with a higher level of trust, unlike other groups. Through APG, the families were also formally part of the Confederation of Indigenous Peoples in Bolivia (CIDOB), which was again part of the Coordinator of Indigenous Organizations of the Amazon River Basin (COICA). The previous Capitan (who just stepped down before our research began) had been very active in environmental topics and in these two overarching groups. The groups mentioned were regarded by the local actors as necessary for their way of life, where food is a very important component of survival and cultural identity.

Another unique form of social self-organization in Kenya is CFA anchored on Participatory Forest Management (PFM) - an approach that is provided for in the Forest Act 2005 (an outcome

\footnotetext{
${ }^{2}$ Table banking is a group savings and credit strategy where members of a particular group meet once every month, place their savings, loan repayments, and other contributions on the table then borrow immediately either as long-term or shortterm loans to one or a number of interested members.
} 
of many years of advocacy by stakeholders) that deliberately involves the adjacent communities and other stakeholders in management of the forests within a framework that contributes to community livelihoods. Through this arrangement, communities that live near forests derive several benefits from the forest resource as agreed upon jointly by Kenya Forest Services, while at the same time contributing to restoring the forest through afforestation activities. Although initially there were fears from stakeholders that communities would destroy the forests if allowed to cultivate, studies have shown that 4,000 ha of forest plantation forest land has been added since 2008 when the "shamba" (farm) system was rebranded into the Plantation Establishment for Livelihood System (PELIS) program (Witcomb and Dorward 2009; Kagombe 2014; Agevi et al. 2016). Although CFAs have contributed to afforestation, this arrangement has also contributed to forest fragmentation and degradation attributed to replacement of indigenous trees with exotic species as well as land use and land cover changes (Kariuki 2006). Under PELIS, practices such as charcoal production, grazing, crop production and logging which has been on the increase due to high demand, have increased. These activities threaten ecosystem services provided by forest ecosystems such as Mt. Kenya including; provision of water, wildlife habitats, carbon sequestration and storage, erosion prevention and recreation and tourism. Apart from these activities, the practice has also been associated with corruption and bad governance that continues to allow unauthorized loggers and farmers into the forests (Kariuki 2006). Deforestation is also common in Bolivia attributed to extractivism, mechanized agriculture, expansion of cattle ranching, slash and burn agriculture, and forest fires (Muller et al. 2012).

Apart from land for farming, communities have various other user rights at a small fee including collecting fuel wood and grazing. For each cow that grazes in the forest and bunch of firewood collected, the farmers pay to Kenya Forest Services an estimated 1 USD per month. In addition, farmers tend tree saplings on state-owned forestland in return for being permitted to intercrop food crops until canopy closure (Witcomb and Dorward 2009). In the high and medium potential areas, Eucalyptus grandis and E. saligna, Grevillea spp. and Casuarina spp. were the most common species while in the drylands Melia volkensii, E. camaldulensis, Azadirachta indica and Acacia spp. were preferred. The choice of tree species to be planted in the forest is agreed upon through consultation between CFAs and Kenya Forest Services and it includes both exotic trees and indigenous species. Stakeholders who support the system argue that it cultivates positive conservation attitudes among the local communities, contributes to food security and local livelihoods, it's a cost-effective form of afforestation and involves the community in forest management in line with current trends of natural resources management.

There are two main cooperatives in the study area dealing with milk production and milk value chains, the New Kenya Cooperative Creameries (KCC) and the Meru Central Cooperative (MCC). Additionally, Brookside, a private entity also contracted farmers to supply milk to its factory. Twenty percent of the smallholders in the study belonged to cooperatives where milk was collected at the farm gate by brokers/middlemen mainly on motorcycles and delivered to cooling plants (e.g., New KCC cooling plant in Nanyuki town). In this case, the farmers paid for transport costs to deliver the milk and the processing/cooling plant paid the brokers who then paid the dairy farmers. As a result, the middlemen/brokers captured sometimes twice the value of the milk at the expense of the farmers who sometimes did not meet the production costs. Cooperatives in Kenya's dairy industry, apart from providing market for milk also had other benefits including training on animal husbandry, feeding, calving, hygiene, and sanitation (Interview with Community Liaison Officer at Nanyuki KCC cooling plant).

The self-help women's groups locally known as chamas (rotating savings and credit associations) established table banking through which they accessed small amounts of money, which helped in purchasing goods and services as well as cushioning against shocks. These groups exhibited a high level of trust, transparency, and reciprocity: exchange of agricultural tools, seeds, labor, money, and knowledge characterized the social interaction. One such group is the Gwika wega ("doing good") women's group in Muramati village in Laikipia East, which was formed in 2007. The group's main objective was to raise money to buy water tanks for each of its 
thirty-six members in order to deal with water scarcity attributable to droughts. The other solution they mentioned for water shortage was to plant trees since the area is semi-arid and they perceived this action to contribute to increased rainfall in the long run. However, they were constrained by water shortages attributed to unreliable rainfall and drying-up (during droughts) of the only stream in the area. The plan to plant trees was also adversely affected by destruction of the tree nurseries by wild animals, especially Elephants.

Common Interest Groups were another form of social self-organization mainly present in Kenya. These are informal association of individuals organized on the basis of one or more shared concerns and attempts to influence public policy to benefit themselves or their causes. Actors at production and processing levels organized themselves in such groups as Potato Growers, Tomato Producers, Cereals Growers Association (CGA), and Cereals Millers Association (CMA), among others. These groups helped in sharing knowledge on best farming methods, improved seed varieties, control of diseases, and access to markets. Cereals growers were particularly concerned about cartels that caused an artificial shortage and flooded the market with cheap imports thereby affecting prices of locally produced wheat and maize. In addition, the smallholders mentioned skills in agroforestry, soil erosion control, and crop rotation. The actors at the production level, especially women, exchanged seeds as a way of enhancing resilience. A notable achievement by actors in the local potato value chain was successful lobbying for improved prices and uniform packaging to reduce exploitation by middlemen.

Unlike in Kenya, the Guaraní Indigenous people had a strong cohesion of families, with the Capitan (Mburuvicha in Guaraní) as the highest authority in the villages. The state was perceived as absent or, if present, threatening through ongoing resource extraction. However, this perspective was not shared by all community members since some had jobs in the state-owned oil industry. Similarly, private landholdings surround the Guaraní communal lands, many of them devoted to agro-industrial production, invading the communal land from different sides (Llanque, unpublished). In addition, jobs in the agro-industrial sector created divisions within the respective villages.

As a more overarching picture, in Kenya the smallholders participated in agro-industrial food value chains through contract farming, while smallholder farmers in the Santa Cruz Department of Bolivia competed in agribusiness value chains individually. At the same time, they remained excluded from the benefits through higher costs of production and lower farm gate prices than medium- and large-scale farmers. McKay and Colque (2015) described this process as a phenomenon of "productive exclusion" in the soybean sector of Bolivia, where small-scale farmers cannot equally benefit from the development and end up renting out or selling their land, which is then not used for food production anymore.

\section{Motivation and Benefits Associated with Social Self-Organization}

When we asked actors in Kenya why they joined natural resource based groups, almost all the producers told us they wanted to have access to natural resources for their operations i.e., mainly water and land. One woman interviewed who belonged to a CFA said she did not have land for cultivation, and that the land in the forest allocated to her was her only source of livelihood. Those belonging to WRUAs were motivated to join water projects to enhance access to water. However, power relations associated with water projects meant that smallholders were often marginalized (Kaeser 2018; Mutea, Rist, and Jacobi 2020). In Bolivia, we noted a two-fold motivation and associated benefits of social self-organization in the Guaraní food system. The first motivation was to negotiate and plan via the Capitanías, territorial administrative units which were recognized in the 2009 Constitution, and the APG. The APG was founded in 1987 in the process of struggle for land rights. Indigenous land rights in Bolivia were legally recognized in 1996. Grassroots organizations among the Guaraní communities had been formed to advocate for land rights in the first place, and for sharing of benefits accruing from crude oil and the need to protect the integrity of their lands. 
Another form of social self-organization especially among women was to enhance access to credit. Smallholders' access to credit in Kenya has been constrained by lack of collateral since most of them do not have title deeds for the land they own. This challenge is more pronounced among women who face various obstacles in accessing finance especially from banks and micro financing institutions. A study in Nakuru (urban area) observed that 60 percent of women in the sample were not able to access credit from microfinance institutions (Waita 2012). This percentage could be even higher in rural areas. Title deed, which is often requested as collateral by banks, disenfranchises the majority of women who do not own land. Out of $10.1 \mathrm{M}$ ha of titled land in Kenya, women own only 163,253 ha representing 1.62 percent of the total and around 5-6 percent of registered titles held in joint names. On the other hand, men own $9.9 \mathrm{M}$ ha representing 97.7 percent of the total (Kenya Land Alliance 2004). Rotating savings and credit associations registered as self-help groups have become important alternative avenues through which women can access credit to build resilience. This was also the case in Bolivia where groups were formed to be able to access micro financing schemes (such as the programs Progenero or Pro Mujer). With limited off-farm employment in rural areas, the small amounts serve many purposes from production (especially purchase of inputs such as seeds, fertilizers, pesticides, and labor) and consumption (during droughts) to health and education. During the focus group discussion with one such group in Kenya, they said, saving and borrowing had been their first objective; however, with time, they diversified their activities to include buying water tanks for members. Women limited access to credit was also reported in Bolivia where the mothers' club was described by its members as being used for finding solutions for family issues and health problems.

Further, in both countries spontaneous organizations existed for certain community activities like festivities, according to the needs of the communities. Furthermore, there was a high level of support and collaboration between women in the two countries, for example, they often gathered to cook together especially during social functions for the case of Kenya and as a way of promoting traditional dishes in Bolivia. A community organization was in the process of being founded among the Guaraní in order to access funding schemes such as the Indigenous Fund that requires people to be organized in associations, thus responding to an external impulse. For the same reason, the women's groups were also in the process of linking themselves to the nationwide group of indigenous women farmers known as "Bartolina Sisa" in Bolivia. These spaces were exclusively occupied and organized by the women of the village. We observed that in the mixed spaces, women had secondary tasks and were more excluded. We also observed that the religious communities that were present in both countries (Catholic and evangelical in this case) played a role in a pronounced ideological division of the village along the lines of their members. In Bolivia, catholic and evangelical families did not work with each other, which was expressed in a rupture of reciprocity mechanisms such as sharing mutual support through labor, exchange of harvest surplus or food, affecting the cohesion of the community.

The Guaraní groups were vertically organized, with the family and community level governed by a local authority, the Capitan, and the Guaraní communities united in the APG at the international level. APG topics were almost exclusively related to access to land and were thus related to the food system via the Guaraní territory. The APG was also involved in discussions with the oil and gas companies about environmental and social impacts of oil exploration as well as benefit sharing mechanisms. They were able to establish the legal community land, but with mixed success. "Interest groups," such as the women's groups, who gathered and worked together, generated reciprocity within families and within the community through persisting mechanisms of reciprocity and redistribution regarding food and natural medicine (Gouldner 1960). Interest groups were also common in Kenya whose motivation was different from the land issues in Bolivia. Common Interest Groups (CIGs) at the production level was lobbied for policy changes on matters related to prices and access to markets for crops such as potatoes, maize, and wheat. At both production and processing level, there were also campaigns to reduce imports of cheap maize and wheat, which was perceived as reducing market and prices for locally produced 
products. It should be noted here that social self-organization at the level of consumption was very limited in the study area, and perhaps this reflects the situation in the county where consumption-related movements are scanty.

\section{Assessment of Indicators of Social Self-Organization}

We rated the indicators of social self-organization from non-existent (0) to very high/ideal (4), as explained under "Data Analysis" in the "Materials and Methods" section. When analyzing and rating the coded information on the selected indicators, our attention was drawn to the fact that all indicators were below medium or medium, except the local consumption of products.

\section{Decentralization and Independence}

Decentralization and independence were strong in Kenya with a score of 3 meaning inputs and markets are partly external and partly local. Some smallholders participated in outgrower scheme that enabled their products to be sold in European markets. This outgrower scheme also had some inputs from external sources such as pesticides and fertilizers. This indicator received a score of 2 in Bolivia for several reasons: first, independence of traditional production system was disappearing; second, there was an increasing dependency on middlemen with food increasingly bought from the outside; third, some seeds - particularly maize and beans, which are the traditional staple food - came from external institutions who distributed certified seeds, and were not reproduced by the communities anymore. On the contrary, smallholders in Kenya saved their own seeds which they used most of the seasons although there was pressure from government for farmers to adopt certified seeds produced by seed companies. Nevertheless, in both countries, women made an effort to maintain some traditional recipes and medicines. In Bolivia, the dependence of the communities on employment at the state-owned oil and gas extraction firm seemed to have both positive and negative effects on the community. On one hand, it created royalties for the Capitanías, even though these funds were not managed transparently by local authorities, and villagers mentioned in informal conversations that they were not benefitting. We were unable to investigate more details about this important indication of unequal access to the royalties. On the other hand, it implied oil and gas extraction on their land, with all potentially relate negative impacts on health and the environment (Oxfam 2010).

\section{Appropriately Connected}

In terms of connectivity between local food systems, the score was 2 meaning there was connection and cooperation, between some, but not directly between all food system stages (e.g., no direct connection between producers and consumers) (Figure 2). A small proportion of smallholders were contracted by export-oriented horticulture farms to grow vegetables for export on their land (Peter et al. 2018). However, the proportion of smallholder farmers involved in agro-industrial food systems as out-growers was only $12 \%$ among adjacent households. Some studies have seen this arrangement as contributing significantly to food security and livelihoods of smallholders (Ulrich, 2014; Van den Broeck and Dercon 2011) despite the fact that monthly wages are low (KES 6,780/US66) for skilled workers and KES 5,436/ USD 53, for unskilled workers. 


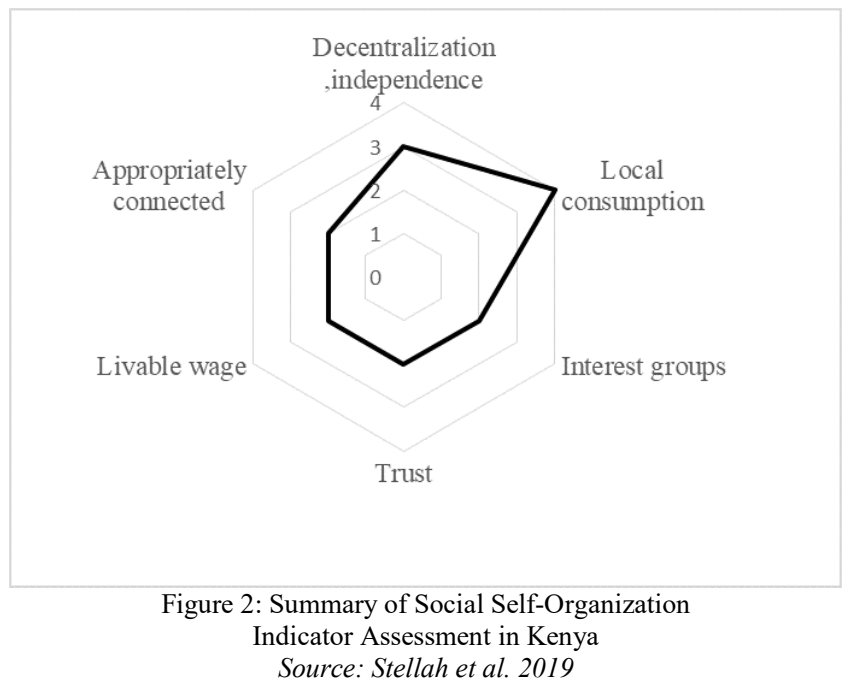

\section{Local Consumption}

The highest possible score of 4 was given for consumption of local food products (3). The smallholders consumed at least 74 percent of the food they grew while a small proportion $(26 \%)$ was sold to the local markets. However during droughts when food supply from the farm was low, the local markets provided alternative sources of food meaning that the consumption from the market increased. With regard to seeds for planting, there was heavy reliance on seeds purchased from shops and very little use of indigenous varieties (Wakuyu 2018). Likewise in Bolivia, one hundred percent of what families produced was used for food and feed within their households and for their livestock. This result was also confirmed by another study on agrobiodiversity in the same study area (Catacora-Vargas 2016; Wakuyu 2018). However, these communities purchased more than half of their food.

\section{Livable Income}

Livable income is an important indicator of food system functionality measured by considering wages received by actors offering their labor as well as income from sell of farm produce. In Kenya the indicator scored 2, since the income was low but slightly above the minimum wage, but not sufficient to meet food security needs of the majority of smallholder households. On average, smallholders raised KES 8,020/USD 79 from the sale of food products with additional irregular income from livestock, which was kept as a form of investment. Income for smallholders was very variable due to crops and livestock types, climate variability, and associated impacts like floods and droughts. In Bolivia, the monthly incomes-which we derived from another study based on fifty livelihood interviews in the same region - received the lowest score (also in comparison with other food systems in the same region (Figure 3), with earnings averaging BOB 1,200/USD 170 while the official minimum monthly wage stood at BOB 2,000/USD 284 at the time of research (Catacora-Vargas 2017). These sub-living wages render households vulnerable and lead to abandonment of food system activities as well as to migration. The poor earnings help explain the many off-farm activities pursued by men-especially work on oil fields - such that the majority of men are absent from the community for weeks on end, returning home periodically for visits of just a few days. This phenomenon leads to economic dependence among women, children, and elderly people, and reportedly involves high rates of domestic violence (Llanque unpublished). 


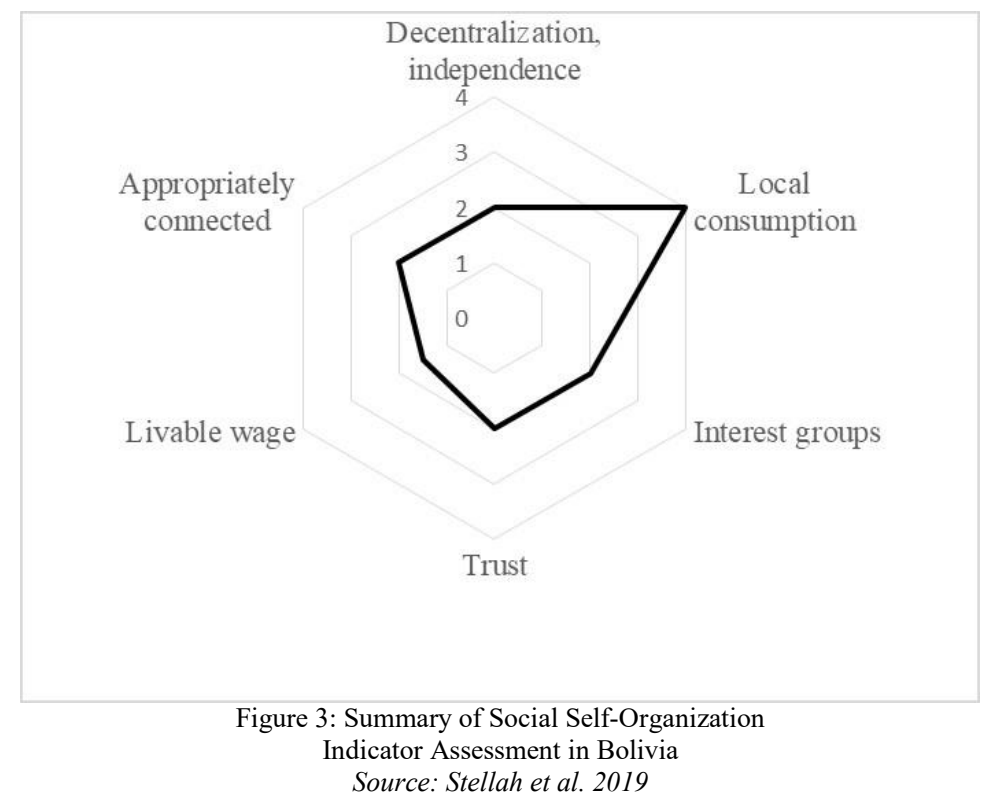

\section{Interest Groups}

The smallholders and the Guaraní indigenous peoples both had a score of 2 for interest groups. This mean than there were limited interest groups restricted to only one food system level mainly production. In another study, we found that the surrounding agro-industrial food systems in both countries had more interest groups and a low level of trust, and the agro-ecological food system in Bolivia, had more trust and transparency but fewer interest groups. The diametric relationship between the number of interest groups and the level of trust may stem from a need of formalization of group affiliation where reliance on trust is not possible either due to the size of the food system, or the different visions and needs within it.

Connectedness was also rated "medium," in Bolivia (Figure 3) because even though production, processing, distribution, and consumption were connected with many nodes and solidarity networks at the community level, the connections with exogenous food system actors were few, and characterized by unequal power relations (Jacobi and Llanque 2018). Connections with local policy-making were weak in terms of the Cabezas Municipality which did not take sufficiently into account the 11 Guaraní communities in the Municipality in their decisionmaking and activities. For example, they implemented a project for beekeepers, ignoring the Guaraní beekeepers association. Similarly, a member of an international development organization explained that his organization did not work with Guaraní communities, because they were - in his words - resistant to their recommendations.

\section{Trust Relationships}

With regard to trust among actors in smallholder agriculture in Kenya, the score was 2 (medium), meaning there was some degree of trust among producer groups such as cooperative members, CIGs and women's groups; however, there was little or no trust between these groups with other actors at transportation and processing levels. The highest level of trust was observed among women groups and since the level of trust among other value chain actors was low, this made the aggregated score to be 2. For instance, there was no trust between producer groups and middlemen who were perceived to be exploiting them while at the same time, the consumers did not trust the millers who were perceived to buy maize from smallholders at low prices and sell 
the flour at exorbitant prices. This was the same for Bolivia where the level of trust between food system actors was also 2 (medium) because, while it was high among community members (who represented production, processing, and consumption), it was low between community members and intermediaries selling exogenous food. Similarly, trust was rather low towards external input providers of seeds and pesticides.

In 5 percent of households surveyed in a previous study in Kenya, at least one household member had worked on a horticulture farm (Mutea et al. 2019). The most important technologies transferred from the agro-industrial food system to smallholders were greenhouse farming and drip irrigation. There were also some cases where horticultural farms provided water during long dry spells to smallholder farmers although this was perceived by locals as not useful since these farms were alleged to be responsible for excessive abstraction of water that often caused the water shortages in the first place (Lanari 2014; Lanari, Liniger, and Kiteme 2016). Besides attributing water scarcity to global environmental change (Notter et al. 2007), studies have shown that shortage of water in Mount Kenya region can be attributed to excessive abstraction for irrigation agriculture (Eschbacher, Liniger, and Weingartner 2005). For instance, abstraction of water in upper Ewasongiro River was 12,614 m3 per day in 1997 and this increased to $17,017 \mathrm{~m} 3$ per day in 2002 and 25,000 m3 / day in 2013 (interview with the Director for Centre for integrated Training and Research in Arid Development (CETRAD) Nanyuki, Laikipia County).

There were different types of interactions between the Guaraní food system and surrounding food systems. For example at the production level, we found large-scale monocultures on Guaraní communal land, reportedly rented out to agro-industrial producers illegally (without the consent of the community). In the Guaraní villages, interviewees reported that several villagers worked for agribusiness companies and Mennonite colonies who, among other things, produced soybeans, and also that these different actors intruded on communal Guaraní lands under conditions that lacked transparency. Companies' extension services and local shops sold agrochemicals not only for extensive cash crops, but also for local food crops, and taught local actors to use them, for example on maize and vegetables. At the consumption level, there was interaction with agro-industrial food systems regarding food grains and cooking oil (e.g., made from soybeans). Another example of interaction between food systems was a Catholic residential school in the municipality of Cabezas, which produces its own food with agro-ecological practices and provides courses to adjacent communities, including Guaraníes. Several families whom we visited in the Guaraní villages participated in these courses and applied the contentsmainly kitchen gardening and preparation of healthy food in their homes.

\section{Outcomes of Social Self-Organization on Social-Ecological Resilience}

Articulation of various challenges facing food systems by groups was seen as an important step in finding solutions that contribute to building resilience. Producer groups such as CFAs and WRUAs and individual farmers were found to be instrumental in resource conservationafforestation, sensitization on protection of riparian areas and sharing of knowledge and skills on soil erosion control, and conservation agriculture (Dessie, Wurzinger, and Hauser 2012; Meijer et al. 2016). This, to some extent, played an important role in strengthening communities' resilience capacities with regard to management of natural resources (water, soils, and forests) necessary for supporting food systems. This is against the backdrop of the problem of deforestation witnessed in the two countries. CFAs therefore provide vital lessons on benefits to communities associated with participatory forest management however there are various long term environmental costs that should be looked into to create a win-win situation for livelihoods and ecosystem integrity.

Social self-organization associated with women's groups provided mutual support not only regarding activities related to food, but also health, reciprocity, funerals, sickness and weddings, in addition to access to credit that was useful at production and consumption levels of food systems. Even though the level of trust between producers and brokers was limited, they played 
an important role in facilitating farmers' access to markets. Measures to develop trust between them would help maximize benefits while high level of trust among women groups is perhaps one useful lesson for many other groups that intent to forge a common future.

Although social self-organization is important for building resilience, it should be noted that buffering the food system against shocks by building livelihood assets and learning and adaptation are also essential (Speranza, Urs, and Rist 2014). In a food system where actors are self-organized, effort should also be made to buffer the system by enhancing livelihood assets at individual and community level to cushion it against shocks. Likewise, as food system undergo changes related to social, economic, ecological and even political dynamics, its eminent that actors learn from past events and build adaptive capacity for future shocks. Without this the food system will be left vulnerable, making coping and recovery from shocks difficult.

Food systems with higher levels of social self-organization in several stages of the value chain have the potential to recover from shocks, and are therefore likely to be more resilient than those where individual actors depend on their own resources for survival (Margis 2010). The aspects of the community that build resilience include decentralization and independence, trust relationships, a high level of connectivity, a livable income and that a community that is potentially self-sufficient and at the same time well-connected regarding their food supply.

Although social self-organization at community level is important, groups tend to achieve more change and impact if they connect to movements at national or global scales to articulate issues of common interest (Sage 2014). This becomes evident for instance in Kenya, where organic farming networks at national level advocate for environmental friendly farming free from chemicals (Okalebo and Woomer 2003; Goldberger 2008). On the other hand, in Bolivia social self-organization around indigenous land rights transcended national boundaries. As an impetus for change, social self-organization helps communities to develop a common vision for a more sustainable future and connect globally.

\section{Conclusion}

We assessed and discussed social self-organization as an important component of socialecological resilience among smallholders and indigenous communities. We obtained several insights on social-ecological resilience in two different exemplary food systems, one in Kenya, and one in Bolivia. Despite the many risks that the actors faced, coming together helped to lessen the burden they would have faced individually-hence there is a possibility that they can cope with the shocks and stress they face, and receive the attention they require. Additionally, strong groups, especially at village level and those associated with women, although they promoted primarily socio-economic resilience, actually had many benefits for the food system, for instance afforestation programs and rehabilitation of riparian areas. Since some groups were formed out of the need to access natural resources (such as CFAs and WRUAs in Kenya), that were shared, there existed immense heterogeneity and inequality in terms of access to resources (especially in WRUAs), which contributed to struggles of power relations, sometimes compromising the cohesion of groups. It was therefore interesting to see how groups overcame these differences and endeavored towards defining common futures.

The dominance of large, often multinational, companies in either horticultural production in Kenya, soybean production and oil and natural gas exploitation in Bolivia had both costs and benefit implications for the food systems. In Kenya, there were some positive and negative outcomes of interaction between smallholders and agro-industrial food system. On the other hand, the Guaraní indigenous people have a long history of grassroots organizations against labor exploitation and encroachment on their common pool resources-more recently by multinational and local oil and gas companies - and the need for territorial integrity and access to benefits. Without their territories, the actors in this food system would be constrained in supporting landbased livelihoods. By analyzing the forms of organization for resistance, negotiation and 
productive activities, the study reveals insights on how social self-organization can contribute to resilient food systems.

There are, however, areas of social self-organization which the study did not investigate that require in-depth assessment. These areas include the possibilities that marginalized food system actors have to form interest groups to increase their bargaining power and lead to collective action from local to global policy levels, and under which circumstances their links with other food systems and other food system actors can create positive resilience outcomes.

Further research on social self-organization should therefore consider its contribution to policy change across scales. One such area is the possibility that participatory forest resource management can evolve into global considerations for carbon credits to farmers who contribute to reforestation in countries or regions where forest cover is at critically low levels. How small projects started by groups at community level are upscaled with the help of external actors to support sustainable livelihoods at a macro level is also an important area of research. Additionally, analysis of how local groups connect to larger movements to be internationally visible may also reveal interesting insights on how farmer movements help to shape global debates on various topics such as agro-biodiversity, indigenous/local knowledge, land rights, and food sovereignty. Such studies will require both quantitative and qualitative research, conducted in a transdisciplinary way together with farmers and social movements.

\section{Conflict of Interest}

The authors declare that the research was conducted in the absence of any commercial or financial relationships that could be construed as a potential conflict of interest.

\section{Funding}

This work was conducted within the Swiss Programme for Research on Global Issues for Development (r4d program), funded by the Swiss Agency for Development and Cooperation and the Swiss National Science Foundation [Grant number 400540_152033].

\section{Acknowledgements}

The authors would like to thank Swiss National Science Foundation, Swiss Programme for Research on Global Issues for Development and Swiss Agency for Development and Cooperation for financial support and the smallholders in Mt. Kenya region and Guaraní indigenous community in Bolivia for sharing their experiences about their food systems.

\section{REFERENCES}

Adger, Neil. 2000. "Social and Ecological Resilience: Are they Related?" Progress in Human Geography 24 (3): 347-64. https://doi.org/10.1191/030913200701540465.

Agevi, Humphrey, Kaleb M. Adamba, Hillary Koros, Carolyne Mulinya, Rashid K. Calvince, Donald K. Kipruto, MosesWabusya, Mercy Khanyufu, and Stanely Jawuoro. 2016. "PELIS Forestry Programme as a Strategy for Increasing Forest Cover and Improving Community Livelihoods: Case of Malava Forest, Western Kenya." American Journal of Agriculture and Forestry 4 (5): 128-35. https://doi.org/10.11648/j.ajaf.20160405.13.

APIA 2017. Asociación de Proveedores de Insumos Agropecuarios [Association of Agricultural Supplies]. http://www.apia-bolivia.org/

Arrow, Holly, Joseph E. McGrath, and Jennifer L. Berdahl. 2000. Small Groups as Complex Systems: Formation, Coordination, Development, and Adaptation. Newbury Park, CA: Sage. 
Burt, S. Ronald. 2000. "The Network Structure of Social Capital.” In Research in Organizational Behavior, Vol. 21, edited by R.I. Sutton and B.M Staw, 345-423. Greenwich, CT: JAI Press.

Cabell, Joshua, and Myles Oelofse. 2012. "An Indicator Framework for Assessing Agroecosystem Resilience." Ecology and Society $17 \quad$ (1): 18. https://doi.org/10.5751/ES-04666-170118.

Carpenter, Steve, Brian Walker, J. Marty Anderies, Nick Abel. 2001. "From Metaphor to Measurement: Resilience of What to What?" Ecosystem 4 (8): 765-81. https://doi.org/10.1007/s10021-001-0045-9.

Catacora-Vargas, Georgina. 2016. "Agrobiodiversidad en Sistemas Alimentarios Agroindustrial, Indígena y Agroecológico en tres Municipios de Santa Cruz, Bolivia" [Agrobiodiversity in Agroindustrial, Indigenous and Agro-Ecological Food Systems in Three Municipalities of Santa Cruz, Bolivia]. Master's Thesis. Universidad Mayor de San Simón, Cochabamba, Bolivia.

Catacora-Vargas, Georgina, Karen Udaeta, Juan P. Torrico, René Quispe, Dagner Salvatierra, Heditt Foronda, Dennis Méndez, Julio Herrera, Carmen Sotomayor, Delia Rojas. 2018. "Maíz y Vivir Bien: Agrobiodiversidad Nativa Como Expresión Biocultural del Bienestar Colectivo en Bolivia." [Corn and Live Well: Native Agrobiodiversity as a Biocultural Expression of Collective Well-Being in Bolivia] Agua y Medio Ambiente. Revista Técnica del Ministerio de Medio Ambiente y Agua [Water and Environment. Technical Journal of the Ministry of Environment and Water] 2 (2): 17-664. https://doi.org/10.13140/RG.2.2.29194.93126.

Colonna, Paul, Stephane Fournie, and Jean-Marc Taizard. 2013. "Food Systems" In Food Systems Sustainability Insights from DuALIne, edited by Catherine Esnouf, Marie Russel and Nicolas Bricas, 69-100. Cambridge: Cambridge University Press.

Carrington, Peter J., John Scott and Stanley Wasserman, eds. 2005. Models and Methods in Social Network Analysis. New York: Cambridge University Press.

Davidson, J. Debra. 2010. "The Applicability of the Concept of Resilience to Social Systems: Some Sources of Optimism and Nagging Doubts." Society and Natural Resources 23 (12): 1135-49. https://doi.org/10.1080/08941921003652940.

Dessie, Yinager, Maria Wurzinger, and Michael Hauser. 2012. "The Role of Social Learning for Soil Conservation: The Case of Amba Zuria Land Management, Ethiopia." International Journal of Sustainable Development \& World Ecology 19:258-67. http://doi.org/10.18461/ijfsd.v9i5.957.

Dhraief, Mohamed Z., Boubaker Dhehibi, Hamed Daly Hassen, Meriem Zlaoui, Chaima Khatoui, Sondes Chemni, Quessama Jebali, and Mourad Rekik. 2019. "Livelihoods Strategies and Household Resilience to Food Insecurity: A Case Study from Rural Tunisia." Sustainability 11 (907): 2-17. https://doi.org/10.3390/su11030907.

Elrick-Barr, Carmen E., Benjamin L. Preston, Dana C. Thomsen, and Timothy E. Smith. 2014. "Toward a New Conceptualization of Household Adaptive Capacity to Climate Change: Applying a Risk Governance Lens." Ecology and Society 19 (4): 12. https://doi.org/10.5751/ES-06745-190412.

Ericksen, J. Polly. 2008. "What is the Vulnerability of a Food System to Global Environmental Change?" Ecology and Society 13 (2): 14. http://www.ecologyandsociety.org /vol13/iss2/art14.

Ericksen, J. Polly, Hans-Georg Bohle and Beth Steward. 2010. "Vulnerability and Resilience of Food Systems." In Food Security and Global Environmental Change, edited by John S. I. Ingram, J. Polly Ericksen, and Diana M. Liverman, 67-77. London: Earthscan. 
Eschbacher, Josh, Hanspeter Liniger, and Rolf Weingartner. 2005. "River Water Shortage in a Highland-Lowland System: A Case Study of the Impacts of Water Abstraction in the Mount Kenya Region." Mountain Research and Development 25 (2):155-62. https://doi.org/10.1659/0276-4741(2005)025[0155:RWSIAH]2.0.CO;2.

Esnouf, Catherine, Marie Russel, and Nicolas Bricas. 2013. Food Systems Sustainability Insights from DuALIne. Cambridge: Cambridge University Press. https://doi.org/10.1017/CBO9781139567688.

FAO, IFAD, UNICEF, WFP, and WHO. 2017. The State of Food Security and Nutrition in the World 2017. Building Resilience for Peace and Food Security. Rome: FAO. http://www.fao.org/3/a-I7695e.pdf.

Folke, Carl. 2016. "Resilience (Republished)." Ecology and Society 21 (4): 44. https://doi.org/10.5751/ES-09088-210444.

Folke, Carl, Steve Carpenter, Thomas Elmqvist, Lance Gunderson, C. S. Holling and Brian Walker. 2002. "Resilience and Sustainable Development: Building Adaptive Capacity in a World of Transformations." AMBIO: A Journal of the Human Environment 31 (5): 437-40. https://doi.org/10.1579/0044-7447-31.5.437.

Folke, Carl, Stephen R. Carpenter, Brian Walker, Marten Scheffer, Terrv Chapin, and Johan Rockstrom. 2011. "Resilience Thinking: Integrating Resilience, Adaptability and Transformability." Ecology and Society $15 \quad$ (4): 20. http://www.ecologyandsociety.org/vol15/iss4/art20.

Fuchs, Christian. 2006. "The Self-Organisation of Social Movements." Systemic Practice and Action Research 19 (1): 101-37. https://doi.org/10.1007/s11213-005-9006-0.

Gouldner, Alvin W. 1960. "The Norm of Reciprocity: A Preliminary Statement." American Sociological Review 25:161-78. https://doi.org/10.2307/2092623.

Goldberger, R. Jessica. 2008. "Diffusion and Adoption of Non-Certified Organic Agriculture: A Case Study from Semi-Arid Makueni District, Kenya." Journal of Sustainable Agriculture 32 (4): 531-64. https://doi.org/10.1080/10440040802257371.

Government of Kenya. 2009. Kenya Population and Housing Census. Nairobi: Kenya National Bureau of Statistics.

Hejl, M. Peter. 1990. "Self-Regulation in Social Systems." In Selforganization Portrait of a Scientific Revolution. Edited by Wolfgang Krohn, Guinter Kuppers, and Helga Nowotny. Berlin: Springer- Science +Business Media.

Imada, Takatoshi. 2008. Self-Organisation and Society. Tokyo: Springer.

Imperial, Mark T. 2004. "Using Collaboration as a Governance Strategy: Lessons from Six Watershed Management Programs." Master's Thesis, University of North Carolina at Wilmington. http://people.uncw.edu/imperialm/Instructor/Papers/A\&S_2004_Final \%20Copy_1_04.pdf.

Jackson, Mathew O., and Brian W. Rogers. 2007. "Meeting Strangers and Friends of Friends: How Random Are Social Networks?" American Economic Review 97 (3): 890-915 https://www.jstor.org/stable/30035025.

Jacobi, Johanna, Stellah M. Mukhovi, Aymara Llanque, Ifejika C. Speranza, Fabian Käser, Horacio Augstburger, Freddy J.M. Delgado, Boniface Kiteme, and Stephan Rist. 2019. "Actor-Specific Risk Perceptions and Strategies for Resilience Building in Different Food Systems in Kenya and Bolivia." Regional Environmental Change 19 (3): 879-92. https://doi.org/10.1007/s10113-018-1448-x.

Jacobi, Johanna and Aymara Z. Llanque. 2018. “'When We Stand Up, They Have To Negotiate With Us' Power Relations in and Between an Agroindustrial and an Indigenous Food System in Bolivia." Sustainability 10 (11): 1-27. https://doi.org/10.3390/su10114001.

Kaeser, Fabian. 2018. "Ethnography of Peasant Engagement in Food Systems." PhD diss., University of Bern, Switzerland.

Kagombe, K. Joram. 2014. Contribution of PELIS towards Increased Tree Cover and Improved Community Livelihoods in Kenya. Nairobi: Kenya Forest Research Institute. 
Kariuki, Joseph. 2006. "Common Heritage, Diverse Interests: Deforestation and Conservation Alternatives for Mount Kenya." Les Cahiers d'Outre-Mer [The Overseas Papers] 235:347-70. https://doi.org/10.4000/com.112.

Keck, Markus and Patrick Sakdapolrak. 2013. "What is Social Resilience? Lessons Learned and Ways Forward.” Erdkunde 67 (1): 5-19. https://doi.org/10.3112/erdkunde.2013.01.02.

Kenya Land Alliance. 2004. The National Land Policy in Kenya - Critical Gender Issues and Policy Statements. Issues paper No. 1. http://www.kenyalandalliance.or.ke/publicationdownloads.

2018. Women, Land and Property Rights and the Land Reforms in Kenya. Policy Brief. Nairobi: Kenya Land Alliance and Federation of Women Lawyers. Nairobi. http://www.kenyalandalliance.or.ke/publication-downloads.

Kofinas, Gary. 2003. "Resilience of Human-Rangifer Systems: Frames off Resilience Help to Inform Studies of Human Dimensions of Change and Regional Sustainability." Newsletter of the International Human Dimensions Programme on Global Environmental Change (IHDP) Update No. 2, 6-7.

Lanari, Nora. 2014. Development of the Commercial Horticulture Sector Northwest of Mt. Kenya from 2003 to 2013 and its Impact on River Water Resources of the Upper Ewaso Ng'iro Basin. Master's thesis. Bern, Switzerland: University of Bern.

Lanari, Nora, Hannspeter Liniger, and Boniface Kiteme. 2016. Commercial Horticulture in Kenya, Adapting to Water Scarcity. CDE Policy Brief. https://boris.unibe.ch/97195/1/CDE_Policy_Brief_08.pdf.

Lanari, Nora, Roland Schuler, Thomas Kohler, and Hanspeter Liniger. 2018. "The Impact of Commercial Horticulture on River Water Resources in the Upper Ewaso Ng'iro River Basin, Kenya." Mountain Research and Development 38 (2): 114-24. https://www.jstor.org/stable/90023307.

Llanque, Aymara. Unpublished. "Laberintos Alimentarios: Transformaciones en la Interaccion de los Sistemas Alimentarios Agroindustrial, Indigena y Agroecologico Desde las Perspectivas de la Pequeña Produccion Agricola, Cado del Municipio de Cabezas del Departamento de Santa Cruz" [Food labyrinths: Transformations in the Interaction of Agroindustrial, Indigenous and Agroecological Food Systems from the Perspective from Small-scale Production: The Case of the Cabezas Municipality in the Santa Cruz Department.] PhD diss., Universidad Mayor de San Andrés [University of San Simon, Cochabamba].

Margis, Kristen. 2010. "Community Resilience: An Indicator of Social Sustainability." Society and Natural Resources 23 (5): 401-16. https://doi.org/10.1080/08941920903305674.

McKay, Ben, and Gonzalo Colque. 2015. "Bolivia's Soy Complex: The Development of 'Productive Exclusion."” Journal of Peasant Studies 4 (2): 583-610. https://doi.org/10.1080/03066150.2015.1053875.

Meijer, Seline, Gudeta W. Sileshi, Delia Catacutan, and Maarten Nieuwenhuis. 2016. "Farmers and Forest Conservation in Malawi: The Disconnect Between Attitudes, Intentions and Behaviour." Forests 25 (1): 59-77. https://doi.org/10.1080/14728028.2015.1087887.

Muller, Robert, Daniel Muller, Florian Schierhorn, Gerhard Gerold, and Pablo Pacheco. 2012. "Proximate Causes of Deforestation in the Bolivian Lowlands: An Analysis of Spatial Dynamics." Regional Environmental Change $12 \quad$ (3): 445-59. https://doi.org/10.1007/s10113-011-0259-0.

Mutea, Emily, Stephan Rist, and Johanna Jacobi. 2020. "Applying the Theory of Access to Food Security among Smallholder Family Farmers around North-West Mount Kenya." Sustainability 12 (5): 1751. https://doi.org/10.3390/su12051751. 
Mutea, Emily, Patrick Bottazzi, Johanna Jacobi, Boniface Kiteme, Ifejika S. Chinwe, and Stephan Rist. 2019. "Livelihoods and Food Security among Rural Households in the North-Western Mount Kenya Region.” Frontiers in Sustainable Food Systems 3:98. https://doi.org/10.3389/fsufs.2019.00098.

Nkhata, B. Abraham, Charles M. Breen, and Wayne A. Freimund. 2008. "Resilient Social Relationships and Collaboration in the Management of Social-Ecological Systems." Ecology and Society 13 (1): 2. http://www.ecologyandsociety.org/vol13/iss1/art2.

Notter, Benedikt, Lindsay MacMillan, Daniel Viviroli, Rolf Weingartner and Hans-Peter Liniger. 2007. "Impacts of Environmental Change on Water Resources in Mt. Kenya Region." Journal of Hydrology 343 (3): 260-78. https://doi.org/10.1016/j.jhydrol.2007.06.022.

Oxfam. 2010. "Case Study: Bolivian Government Consultation with the Guaraní Indigenous Peoples of Charagua Norte and Isoso. Proposed Hydrocarbons Exploration Project in San Isidro Block, Santa Cruz, Bolivia." Ván Bascopé Sanjines Centro de Estudios Jurídicos e Investigación Social (CEJIS) [Ván Bascopé Sanjines Center for Legal Studies and Social Research] La Paz, Bolivia. https://www.oxfamamerica.org /static/media/files/oxfam-bolivia-consultation-process-nov-2010-final.pdf.

Okalebo, J. Robert, and Paul L. Woomer. 2003. "Organic Resources for Integrated Nutrient Management in Western Kenya." In Organic Resource Management in Kenya: Perspectives and Guidelines, edited by Canon E.N. Savala, Musa N. Omare, and Paul L. Woomer, 34-42. Nairobi: Forum for Organic Resource Management and Agricultural Technologies. http://erepository.uonbi.ac.ke/bitstream/handle/11295/39161/Organic\%20 Resource\%20Management.pdf?sequence $=1$.

Peter, M. Ngutu, Salome A. Bukachi, Charles. O. Olungah, and Tobias Haller. 2018. "Opportunities and Challenges in Export Horticulture as an Agro-industrial Food System: Case Study of Northwest Mount Kenya Region." Journal on Food System Dynamics 9 (5): 470-83 https://doi.org/10.18461/ijfsd.v9i5.957.

Rastoin, Jean-Louis, Gérard Ghersi. 2010. "Le Système Alimentaire Mondial: Concepts Et Méthodes, Analyses et Dynamiques" [The Global Food System: Concepts and Methods, Analyses and Dynamics]. Synthèses [Summaries]. Paris. Editeur Quae. https://www.cairn.info/le-systeme-alimentaire-mondial--9782759206100.htm\#.

Resilience Alliance 2010. Assessing and Managing Resilience in Social-Ecological Systems: A Practitioner's Workbook. Version 2.0. https://www.resalliance.org/files/ResilienceAssessmentV2_2.pdf

Rigolot, Cerille, Peter G. de Voil, Sabine Douxchamps, Diane B. Prestwidge, Mark van Wijk, Phillip K. Thornton, Daniel Rodriguez, Benjamin B. Henderson, Medina, D. and Mario Herrero. 2017. "Interactions between Intervention Packages, Climatic Risk, Climate Change and Food Security in Mixed Crop-Livestock Systems in Burkina Faso." Agricultural Systems 151:217-24. https://doi.org/10.1016/j.agsy.2015.12.017.

Roberto, Capone, Hamid E. Bilali, Philipp Debs, Gianluigi Cardone, and Noureddin Driouech. 2014. "Food System Sustainability and Food Security: Connecting the Dots." Journal of Food Security 2 (1): 13-22. http://pubs.sciepub.com/jfs/2/1/2.

Sage, Collin. 2014. "The Transition Movement and Food Sovereignty: From Local Resilience to Global Engagement in Food System Transformation." Journal of Consumer Culture 14 (2): 254-75. https://doi.org/10.1177/1469540514526281.

Sari, J. Himanen, Pasi Rikkonen and Helena Kahiluoto. 2016. "Codesigning a Resilient Food System." Ecology and Society 21 (4): 41. https://doi.org/10.5751/ES-08878-210441.

Speranza, I. Chinwe, Wiesmann Urs, and Stephan Rist. 2014. "An indicator framework for assessing livelihood resilience in the context of social-ecological dynamics." Global $\begin{array}{llll}\text { Environmental } & \text { Change } & 28 & \text { (2014): }\end{array}$ https://doi.org/10.1016/j.gloenvcha.2014.06.005. 
Tendall, Danielle, Jonas Joerin, Brigit Kopainsky, Peter J. Edwards, Aimee Shreck, Quang B. Le, Pius Krütli, Michele Grant, and Johan Six. 2015. "Food System Resilience: Defining the Concept." Global Food Security 6:17-23. https://doi.org/10.1016/j.gfs.2015.08.001.

Ulrich, Ann. 2014. "Export-Oriented Horticultural Production in Laikipia, Kenya: Assessing the Implications for Rural Livelihoods." Sustainability $6 \quad$ (1): 336-47; https://doi.org/10.3390/su6010336.

Van den Broeck, Katleen, and Stefan Dercon. 2011. "Information Flows and Social Externalities in a Tanzanian Banana Growing Village." Journal of Development Studies 47:231-52. https://doi.org/10.1080/00220381003599360.

Waita, Jonathan M. 2012. "Challenges Facing Women in Accessing Credit from Microfinance Institutions in Nakuru, Kenya." Unpublished Master's Thesis, University of Nairobi. http://erepository.uonbi.ac.ke/handle/11295/8227.

Wakuyu, Jackline W. 2018. Effects of Different Food Systems on Agro-Biodiversity in Northwest Mount Kenya: A Focus on Food Crops. Unpublished Master's Thesis, University of Nairobi.

Walker, Brian, Crawford S. Holling, Stephen. R. Carpenter, and Anne Kinzig. 2004. "Resilience, Adaptability and Transformability in Social-Ecological Systems." Ecology and Society 9 (2): 5. http://www.ecologyandsociety.org/vol9/iss2/art5.

Witcomb, Mark, and Peter Dorward. 2009. "An Assessment of the Benefits and Limitations of the Shamba Agroforestry System in Kenya and of Management and Policy Requirements for its Successful and Sustainable Reintroduction." Agroforestry Systems 75 (3): 261-74. https://doi.org/10.1007/s10457-008-9200-z.

Wood, Donna J., and Barbara Gray. 1991. "Towards a Comprehensive Theory of Collaboration." Journal of Applied Behavioral Sciences $27 \quad$ (2): 139-62. https://doi.org/10.1177/0021886391272001.

\section{ABOUT THE AUTHORS}

Dr. Stellah Mikalitsa Mukhovi: Senior Lecturer, Department of Geography and Environmental Studies, University of Nairobi, Nairobi, Kenya

Dr. Johanna Jacobi: Senior Researcher, Centre for Development and Environment, University of Bern, Switzerland

Dr. Aymara Llanque: Postdoc Fellow, AGRUCO, Universidad Mayor de San Simón, Cochabamba, Bolivia

Prof. Stephan Rist: Professor, Institute of Geography, University of Bern, Switzerland

Prof. Freddy Delgado: Agruco, Universidad Mayor de San Simón, Cochabamba, Bolivia

Dr. Boniface Kiteme: Director, Centre for integrated Training and Research in ASAL Development, Nanyuki, Kenya

Prof. Chinwe Ifejika Speranza: Professor, Institute of Geography, University of Bern, Switzerland 
Food Studies: An Interdisciplinary Journal explores new possibilities for sustainable food production and human nutrition. It provides an interdisciplinary forum for the discussion of agricultural, environmental, nutritional, health, social, economic, and cultural perspectives on food. Articles range from broad theoretical and global policy explorations to detailed studies of specific humanphysiological, nutritional, and social dynamics of food. The journal examines the dimensions of a "new green revolution" that will meet our human needs in a more effective, equitable, and sustainable way in the twentyfirst century.

As well as papers of a traditional scholarly type, this journal invites case studies that take the form of presentations of practice-including documentation of socially engaged practices and exegeses analyzing the effects of those practices.

Food Studies: An Interdisciplinary Journal is a peer-reviewed, scholarly journal. 